\title{
Breve estudio de la iglesia cas- trense de la Purísima Concepción de Melilla
}

Juana Alías Rodríguez

\section{Introducción}

Las necesidades del culto religioso de la población de Melilla, se vieron satisfechas en épocas pasadas, con la construcción de capillas e iglesias en el primitivo núclco poblacional, la actual Melilla la Vieja.

La pobreza y escasez de los materiales constructivos así como las necesidades defensivas de la Plaza, dieron lugar a derrumbamientos y traslados frecuentes de ubicación, de los que ha quedado constancia en la documentación escrita.

La masiva afluencia de población, acaecida a principios del siglo actual, conllevó un afán constructivo y la consiguiente expansión desde la ciudad, con barrios nuevos surgidos en ocasiones considerablemtne alejados del casco antiguo.

A la vez que las edificaciones de carácter civil, se construyen edificios religiosos, tales como iglesias parroquiales, capillas adosadas a colegios, hospitales e instalaciones militares.

Tal es el caso de la Iglesia Castrense de la Purísima Concepción, cuya necesidad se hizo patente en los inicios del siglo, aunque su construcción fuera demorada, por causas diversas hasta muy avanzado el primer tercio.

\section{La Iglesia parroquial castrense de la Purísima Concepción}

Constituye un bello ejemplo de edificio religioso situado en una céntrica zona de la ciudad en la calle Duque de Almodóvar, próxima a la Plaza de España.

Desde su construcción hasta la fecha actual, se ha realizado una importante modificación en la decoración interior de la misma, adecuándose a criterios de gusto más modernos, como igualmente ha ocurrido en el resto de los templos de la ciudad, destacando en este aspecto la pérdida de las primitivas vidrieras que representaban las imágenes veneradas en el templo y que correspondían a los patronos de las diferentes armas y cuerpos del ejército.

Se ha respetado el exterior del templo en su totalidad, conservándose actualmente en muy buenas condiciones. Sin embargo, la perspectiva original que se procuró para el edificio se vio afectada con la construcción de unas viviendas militares que se adosaron al lateral izquierdo de la iglesia. 


\section{Breve historia de su construcción}

Por su especial condición de iglesia destinada a satisfacer las necesidades de culto de la población castrense, son así mismo especiales las circunstancias por las que atravesó su edificación. Las disposiciones relativas a la jurisdicción castrense en Melilla se remontan a 1576, fecha en que un Breve Pontificio del 5 de febrero, faculta al obispo de Málaga a nombrar curas y vicarios no sólo para Melilla sino para La Goleta, Argel y demás plazas que fueran tomadas.

El 15 de febrero de 1661, toman posesión los padres capuchinos, que habian sido nombrados por el obispo de la diócesis, con el cargo de Vicario y Comisario de la Santa Cruzada el padre Basilio de Antequera, y, como coadjutores, los padres Félix de Génova y Fulgencio de Estepa.

Existen otras disposiciones (Real Orden de 3 de junio de 1887, tanto para Melilla, como para Alhucemas, Peñón y Chafarinas) relativas a los estipendios que debian recibir los clérigos establecidos en la ciudad.

Por esta fecha no existía un clero castrense y es por ello que los religiosos atendían al personal civil y militar establecido en la Plaza.

Después de la Campaña de 1909, la población de la ciudad empezó a aumentar considerablemente y al igual que se construyeron nucvos edificios de carácter civil también se construyó una capilla castrense junto al Muro $\mathrm{X}$ que tuvo un carácter meramente provisional.

Las obras de la actual capilla castrense se iniciaron en tiempos del General Fernández Silvestre. Es de suponer que el autor del proyecto fue un ingeniero militar, aunque no existen datos acerca de su identidad. Si se sabe que el ingeniero director de las obras fue D. Francisco Carcaño. Así mismo están documentadas las obras realizadas en 1932, en las cuales se ampliaron la sacristía y la vivienda del párroco, siendo en esta ocasión el director de las obras el ingeniero militar Salvador Lechuga.

Cuando en el año 1921 sobrevino la guerra, la parte útil de la inacabada construcción fue utilizada como almacén del parque de artillería. Una vez finalizada la campaña se reanudaron las obras, que finalizaron en 1925, quedando constancia en "El Telegrama de Melilla" de la solemne procesión que tuvo lugar para celebrar la bendición del nuevo templo, siendo Comandante General José Sanjurjo y Sacanell.

Con motivo del "desarme del Rif", se celebró en 1926 una exposición de material bélico en terrenos adyacentes al edificio que nos ocupa, tomándose con dicha motivación fotografías aéreas de la zona y en ellas podemos apreciar la belleza del templo sin el posterior impedimento de los edificios añadidos en su entorno inmediato, destacando las torres de ambos lados de la fachada con su airosa prestancia.

\section{Descripción de los elementos arquitectónicos que conforman el templo}

El conjunto del edificio puede clasificarse dentro del estilo neogótico por una serie de rasgos que a continuación describiremos, aunque por su carácter ecléctico se dan cita en él elementos variados correspondientes a otros estilos.

La planta del templo es basilical (Rosario Camacho Martínez. El eclecticismo en la arquitectura religiosa de Melilla) -aunque sus proporciones son muy reducidas-estando separadas las naves laterales de la central por dos pares de columnas, con haces 
de columnillas adosadas de las que parten las nerviaciones de las bóvedas ojivales con que se cubren las naves. Estas columnas sostienen arcos apuntados que separan la nave central de las laterales. Remata la nave central una capilla semicircular, cubierta a su vez con bóveda cuyos nervios surgen de un florón central.

Al ser la nave central de mayor altura que las laterales, se han situado cuatro óculos a cada lado para proporcionar iluminación al interior. Así mismo confiere gran luminosidad al templo el claristorio conseguido en el muro latcral derecho merced a cuatro ventanales de arcos apuntados, desdoblados por un ajimez, situándose en el tímpano así formado en cada uno de ellos un rosetón calado cuatrilobulado.

La fachada principal presenta movimiento en planta, adclantándose al muro de cerramiento la portada, retranqueándose los laterales de la misma para volver a avanzar de nuevo con los cuerpos de las torres situadas a ambos lados.

Este movimiento en planta confiere un aire barroco al conjunto de la fachada, dominada por elementos góticos como veremos a continuación.

$\mathrm{El}$ arco central, apuntado, se decora en el tímpano con un rosetón calado con igual motivo decorativo que los de las ventanas latcrales. Remata la portada un hastial pentagonal, separado del cuerpo anterior por una imposta decorada con arquillos ciegos trilobulados: decorado en su parte central por un rosetón decorado a base de molduras cn forma de círculos de desigual tamaño, que se entrecruzan. Se remata con crestería calada.

Las dos zonas adyacentes a la portada, con un leve retroceso en planta, se decoran con dos arcos ciegos, apuntados, con función meramente decorativa; semejantes a los que se encuentran formando el claristorio del muro lateral derecho. Sobre estos arcos y a la altura de la parte superior de las naves laterales, continua la misma imposta que decora la parte superior del hastial.

Finalmente, a ambos lados de la fachada se han colocado dos torres gemelas, situadas en planta en el mismo plano que la portada, es decir avanzadas en relación con el muro de cerramiento.

Consta de dos cuerpos, separados por un resalte, ambos de forma cúbica. El primero de ellos, presenta una decoración en la parte superior, de falsos vanos de dobles arcos apuntados trilobulados.

El cuerpo superior contiene dos ventanas en cada uno de los cuatro lados, de arcos apuntados, decorados con molduras en resalto, rematándose la parte superior de cada lado en perfil mitral coronado de crestería calada. Rematan los cuatro ángulos sendos pináculos con gárgolas en sus bases.

Recubren ambas torres chapiteles piramidales, decorados con ganchos en cada una de las cuatro aristas.

El muro lateral derecho, decorado con los cuatro ventanales descritos anteriormente, contiene en los espacios existentes entre las mismas, cuatro pilastras adosadas. La parte superior del muro, se encuentra decorada por una imposta de rombos concatenados, colocándose sobre ella una crestería calada de facción semejante a la que decora la parte superior del hastial y arcos en mitra de las torres, aunque en estas se disponen unas bolas decorativas en sus ángulos superiores. Una crestería semejante decora la parte superior de la nave central.

La zona perteneciente al ábside, así como el muro izquierdo quedan ocultos por los 
edificios que se han adosado con posterioridad a la construcción original.

De la decoración primitiva del interior del templo, realiza una interesante y detallada descripción Enrique Moya y Casals, (Enrique Moya Casals. Melilla piadosa y tradicional. Descripción histórica y artística de los templos de la ciudad. Melilla, 1954) en la cual se especifica la totalidad de altares que existían e imágenes que se veneraban en los mismos. Todo ello se encuentra definitivamente transformado en la actualidad, habiendo desaparecido la casi totalidad de las mismas.

\section{Conclusión}

El modelo arquitectónico al que pertenece esta iglesia, puede encuadrarse dentro de la arquitectura denominada "arqueologizante", que copia elementos del romanico, del gótico, del renacimiento e incluso llega a un eclecticismo creador de estilo híbrido.

En el caso de nuestra iglesia castrense, predominan los elementos góticos: ojivas, rosetones, crestería calada, etc.

Este estilo neogótico, utilizado a principios del siglo $\mathrm{XX}$, resulta tardío, pues sus inicios se remontan al final de la primera mitad del siglo XIX, siendo utilizado en Europa, sobre todo en Inglaterra, donde nunca había sido abolido del todo, y en Estados Unidos.

Contrasta esta construcción, con cl estilo modernista que se impone en la ciudad durante el primer tercio del siglo, que pretende erigirse en un arte original sin relación con el pasado y que utiliza con profusión las formas curvas, contracurvas, alargadas y ondulantes.

Existen, sin embargo, numerosas construcciones semejantes a esta iglesia castrense, basadas en modelos neogóticos, pero sin las pretensiosas dimensiones y profusión de elementos del período inicial. Las características comunes son la fachada dividida en tres cuerpos, con dos torres piramidales a ambos lados y frontón triangular central.

Un ejemplo muy cercano, aunque de dimensiones algo mayores lo tenemos en la Capilla del Cristo de la Cofradía de la Veracruz de Alhaurín el Grande, (Proyecto realizado en 1904 por el arquitecto provincial, José Novillos y Fortrell) en la provincia de Málaga.

Dentro de nuestra ciudad, encontramos otras construcciones religiosas, también de estilo basado en elementos historicistas, bien sean predominantemente góticos, como en el caso del Colegio del Buen Consejo (actual Casa de la Cultura) o románicos, como en la Iglesia del Sagrado Corazón, por destacar los más interesantes. 